\title{
Microfinance as a Strategy of Empowering the Conflict-Affected Communities in Sri Lanka
}

\author{
H.M.W.A. Herath \\ Department of Economics and Statistics, University of Peradeniya, Sri Lanka \\ ariyarathneherath@gmail.com
}

\begin{abstract}
The objective of this paper is to assess the capability of microfinance as a tool of reconciliation through economic activity generation and empowerment in the conflict-affected communities in the Northern and Eastern regions of Sri Lanka. The principal data collection tools for this study were Focus Group Discussions and Key Informant Interviews. The impact of microfinance engagement is in varying degrees with certain areas and groups showing evidence of receiving more beneficial impacts compared to others. It also showed very high involvement of women and those women who are active namely, those from groups above the very poor and those who have comparatively better educational levels. We found that microfinance intervention has both tangible and also created other intangible benefits on clients. The post-conflict Northeastern region is not a monolithic entity and there are a number of diverse groups of potential beneficiaries with different needs, skills, capacities and opportunities. Therefore, microfinance initiatives need to consider these situations and develop their interventions accordingly.
\end{abstract}

Keywords: Microfinance, Empowerment, Northeastern, Post-conflict, Beneficiaries

\section{Introduction}

The discourse on microfinance traverses several fields and interconnects with issues of economic globalization and neoliberal policies, strategies for poverty and vulnerability reduction, and pathways for women's empowerment. Its credibility has grown over the last few decades, including international acceptance of it as a tool for addressing poverty and socio-economic vulnerability. The Microcredit Summit held in Washington DC in 1997, recognized it as a "miracle tool" for poverty reduction. It focused on four themes - reaching the poorest, the empowerment of women, building self-sufficient financial institutions and ensuring a positive and measurable impact on the lives of clients and their families. The United Nations has declared that 2005 as the international year of microcredit, which recognized microfinance as an important way to meet the millennium development goals, particularly the goal of having the world's poverty rate by 2015.It has been recognized that microfinance leads to increase income, helps reduce strains of consumption, and reduces the vulnerability of the poor. By providing the poor with financial services that are flexible and easy to access and aimed at generating economic activities microfinance is considered as an effective means to help break the vicious cycle of poverty.

The original objectives of microfinance which were social upliftment and poverty reduction have expanded gradually during the last three decades with microfinance becoming concerned with what the industry defines as difficult environments (Morduch, 2000; Woller, Christopher \& Warner, 2001). This expansion of microcredit services to include non-traditional clientele began in mid 1980 with microfinance institutions starting to turn their attention to communities that were threatened by endemic diseases (HIV AIDS) or were recovering from a natural disaster or armed conflict. With the ending of conflicts, conflict relief effort shifts from saving lives to saving livelihoods with a greater focus on post-conflict economic reconstruction and capacity building(Bernal-Garcia, 2008). This necessitates the provision of financial services and microfinance is recognized as the effective strategy. As a result, microfinance interventions have become an accepted part of the rehabilitation and economic recovery of post-conflict countries. There is debate however over the desirability of incorporating peace conditionality into the operation of microfinance services as some analysts, especially those who subscribe to financial systems or institutions approach ${ }^{1}$ that advocate financial self sufficiency as an indicator of the success of microfinance institutions(Bernal-Garcia, 2008).

${ }^{1}$ Though microfinance is making inroads into post conflict environments provision of microfinance services is still dominated by financial systems" or "institutionist" approach that advocates profit-seeking and financial self sufficiency, a view that came into microfinance service provision. 
The objective of this paper is to assess the capability of microfinance as a tool of reconciliation through economic activity generation and empowerment in the conflict-affected communities in the Northern and Eastern regions of Sri Lanka. While the main focus of the paper is the minority Tamils who were by far the largest group of victim war from these regions the situation of Muslims who are the second biggest ethnic population of these regions and that of the Sinhalese in border areas also is examined. The literature on microfinance operations in post-war environments demonstrated that poverty alleviation, peace development and vulnerability reduction in these regions, microfinance provides an acceptable mechanism. Postwar environments are facing problems such as lack of resources, widespread poverty, income disparities, lack of opportunities, peacebuilding and some other critical socioeconomic and political issues. At present, almost all of these constraints exist in the Northern and Eastern provinces in Sri Lanka as well. With the objective of helping war-affected communities to break the vicious circle of poverty, Sri Lanka introduced a series of poverty reduction oriented microfinance programs through formal channels. These include the programs by government banks, private commercial banks, Non Governmental Organizations and some other social institutions. However, the achievements of microfinance initiatives have been limited, especially in terms of reaching the poorest of the poor for whom the programs were designed mainly because some of these programs include terms and conditions that are not favorable to poor. Accessibility to the formal financial institution to the poor is limited especially, access to the commercial banks. Private commercial banks are generally more interested in profit making than service. Therefore, they mainly target the commercial sector and largely concentrate on providing commercial and short-term credit to least risk sectors, and the elite.

Meanwhile, some of the microfinance institutions realize that banking with the poor can be profitable, but only if costs are contained, risks are managed and clients treated as active partners in the conduct of the business of the enterprise. Currently, there are several initiatives operating in the sector. Some of them are reaching the poor but their initiatives are not financially viable and sustainable. Some are financially viable with the government or other subsidies but clients are not satisfied with the services provided. Some of them are financially viable and reaching the poor successfully. Therefore, it would be worthwhile to understand and identify the ways by which these microfinance initiatives approach their clients and their results, lessons and impact on clients' socio-economic condition. It is important to understand the impact of microfinance and, whether the war affected poorest can acquire the benefit from microfinance intervention process in terms of increased income, building peace and reduced vulnerability? Accordingly, this study is attempting to make a contribution to the discourse on the capability of microfinance as a tool of reconciliation through economic activity generation and empowerment in the conflict-affected communities in the Northern and Eastern regions of Sri Lanka. This will be useful in designing future programs to replicate these initiatives in the future to achieve reconciliation, poverty and vulnerability reduction targets in other regions and contexts. The discussion in the paper is divided into five sections. In the first section microfinance as a strategy for the upliftment of the poor and vulnerable discussed. In the second part there is a brief examination of microfinance activities in Sri Lanka. In the third section the emerging role of microfinance in post-conflict environments (PCEs) and the special issues and concerns of microfinance institutions in working in the new environment is discussed. The fourth part analyses the problems affecting microfinance interventions in the conflict-affected areas in the North and East of Sri Lanka and potential for better engagement and also proposes a model for microfinance intervention in post-conflict environments. The section five in addition to provided conclusions and recommendations.

\section{Literature Review}

Microfinance as a Means of Helping the Poor and a Strategy to bring Economic Development: Microfinance broadly defined is a type of banking service which provides access to financial and non-financial services to poor and vulnerable groups with the aim of improving their economic and social condition(Otero $\&$ Rhyne, 1994). The financial services provided by microfinance institutions may include accepting deposits 
and provision of credits, payment services to the poor and low-income households and their microenterprises. Non-financial service on the other hand may include depending on the operational context. Services such as those related to the delivery of financial service to those others that improve general social conditions of target communities such as health education, maternal and child healthcare, literacy, language training, legal advice and different kinds of personal mentoring, and micro-entrepreneurial development services, involving financial, business or technical skills training. The wide variety of existing credit-plus activities responds to the belief that microfinance does not always sufficiently improve the living standards of its clients and also for the fact that effective use of financial services need several social skills and resources that the target communities lack (Herath, 2015; Marconi \& Mosely, 2006). The objective of these nonfinancial services is to serve as a long term support to help these communities get the best out of financial services. They therefore can be seen as preparing for the main objective. Microfinance institutions be they a bank, a cooperative, a credit union, and Non Governmental Organization (NGO) or some other form of nonbank financial intermediary, seek to provide clients or low income households with a range of money management and banking services. Broadly, all microfinance providers can be classified into three categories based on their main sources of funding. They are (1) all microfinance providers who depend on other people's money (can be domestic or foreign) to finance their lending activities, (2) formal microfinance providers which use members' money to grant loans exclusively to members, and (3) microfinance providers that use the general public's money to finance their lending businesses. Based on the functional and activities implementing MFIs can be classified as formal institutions, semi-formal institutions and informal institutions.

Microfinance is a development strategy aimed at improving the life of poor and disadvantaged segments of society. The argument of micro-finance is that, the one of the major reasons of poverty is lack of access to credit for those who belong to low income and socially disadvantaged groups. If these people are provided with access to financial assistance, including credit, they will be able to start or expand a micro-enterprise that will allow them to break out of the vicious circle of poverty. In this sense microfinance interventions are core to poverty alleviation efforts. Provision of microfinance service are expected not only help people out of poverty but also through improvement in economic conditions to enable them to take control of their lives. Therefore, microfinance is also considered as a means of empowerment of the disadvantaged social segments, not only the poor but also other groups such as women. Poverty is the condition where people are unable to meet basic needs of food, clothing and shelter and its main indicator is low income. Yet poverty is not a problem of income but also about access to resources in general. Poor people lack social capital that effectively prevents them from accessing services which in turn stand in their way in their effort to improve their life conditions. Poverty is also about the ability to take decisions with regard to life matters of the poor. Poverty also is characterized by social exclusion preventing the poor from integrating not only into mainstream life but also shutting them out of essential services of which exclusion from financial services is the major barrier (Muneer et al., 2017). Poor people are in that position not only for income poverty but also for social poverty (lack of social capital) and by products of these two, namely, social exclusion ${ }^{2}$ and inability control their life choices. Therefore, poverty is also a problem of power, the root cause of which is the low income (income poverty). It is the argument of microfinance that by providing access to easy and flexible financial service, the poor can be made to take up microenterprises leading to economic improvement that in turn would result in creating enabling effect on individuals making them empowered. Therefore, provision of microenterprise, especially its success, needs to be understood in relation to this enabling effect, namely, empowerment.

Empowerment is the process through which people acquire more influence over factors that shape their lives (Rappaport, 1986; Whitmore, 1988). Empowerment enables people to break the grip of exclusion and take control of their lives. Empowerment therefore is an enabling process that increases the status of people to live their life with dignity, humanity, respect, self esteem and self reliance. The poor and the vulnerable are the most affected by lack of power to control factors affecting their lives and therefore among those who are mostly in need of empowerment. Microfinance is regarded as one such policy that seeks to empower those

2 The focus on financial aspects in the alleviation of poverty is disputed (see (Christen \& Drake, 2002; Littlefield, Morduch, \& Hashemi, 2003; RIMHI, 1999). 
who do not have resources, economic, social and psychological, to take control over their lives. Empowerment therefore reduces vulnerability ${ }^{3}$ which is an aspect of poverty that relates to risks, shocks, stresses and internal defenselessness (Lock-Desallien, 1996). It is widely accepted that the microfinance programs have greater empowering potential on women who are a marginalized segment, both economically and socially, all societies. Microfinance services enable women to develop their own income-generating new economic activities, and thereby making them play a greater role in decision making (as greater bargaining power within the household and leadership in the community) and making attitudinal changes (increased selfreliance, self-confidence and self-worth). Further, small groups, which form the foundation of most microfinance programs, empower women through mutual support, exchanging of new ideas, group responsibility and leadership (Herath et al., 2016).

Microfinance with the general goal of improving economic and social condition of the poor and empowerment of members, especially women, in these communities began in Bangladesh in the 1980s with the establishment of the Grameen Bank movement. Today the strategy has received international legitimacy and adopted as not only a poverty alleviation strategy but also alternative development model for holistic development. By the end of 2000 microfinance serviced had reached over 79 million people of the world's poor and the disadvantaged (Noreen, 2011). Further, microfinance operations that initially developed as a donor supported provision of financial services with equal weight for both social and financial objectives have gradually moved towards adopting more financial operation focused approach lately. Today there are two views on the operational strategies that debate on the extent to which microfinance institutions should be self sufficient financially. In this there are two schools of thought with one focusing on giving primacy to financial operations and claiming that MFIs should be profit oriented and self financing and the other claiming that microfinance should adopt a more holistic approach of support with broad social objectives going beyond commercial objectives and profit (Meehan \& Jennifer, 1999; Morduch, 2000; Shaw \& Matthew, n.d; Woller et al., 2001). These two are variously known as financial systems or institutions/minimalist approach and welfare based approach have dominated the discourse on microfinance since the 1990s.Apart from the disagreement on the financial operations related objectives there is an agreement among proponents of microfinance service that the core objective of microfinance services is making poor people easy access to financial services for microeconomic activities.

Access to finance can be defined as "availability of a supply of reasonable quality financial services at reasonable costs, where reasonable quality and reasonable cost have to be defined relative to some objective standard, with costs reflecting all pecuniary and non-pecuniary costs" (Claessens, 2006). Access to finance has numerous benefits. But less than half of the households in developing countries have access to financial services, compared to over 70 percent in the developed world. It is estimated that only one out of every eight people who could benefit from microcredit currently has access to it. By 2006, there were 3,316 microfinance institutions with more than 133 million members worldwide. Of these, 69.8 percent were among the poor (defined as earning less than US\$ 1 a day). Women accounted for 85 percent of poor clients. As regards households, however, the figures tell a slightly different story. Of the 193.6 million poor families worldwide, only 47.8 percent were within reach of microfinance institutions.

Microfinance in Post Conflict Environment (PCE): Microfinance is increasingly being recognized as a useful strategy in the recovery process in post conflict environments (PCEs). It can be an effective means of providing relief and rehabilitation support that are required in the short-term recovery process and strategy with high potential to help boost socio-economic development in the long-term by providing access to financial services to encourage microenterprises(Bernal-Garcia, 2008). While it is generally recognized that microfinance operates under similar principles in both stable and conflict-affected contexts, employing microfinance as a tool in post conflict environments need to consider that PCEs are not normal

${ }^{3}$ (World-Bank, 2002) defines vulnerability as the expected welfare loss resulting from unexpected events and lack of insurance against them. (Chambers, 1995) explains that vulnerability as having an external side (exposure to shocks, stress, and risk) and internal side (defenselessness, meaning a lack of means to cope without damaging loss). 
disadvantaged/vulnerable communities whose main feature is poverty and associated problems such as lack of resources and capacities. Armed conflicts have devastating consequences on socioeconomic development of affected communities. PCEs are characterized by widespread destruction of physical infrastructure and other support systems of which financial and trade operation are the most important, a severely traumatized and dehumanized civilian population, often with a large scale refugee component and social relationships weakened by mistrust and suspicion. In some cases, there may be even ongoing pockets of armed conflict. The primary goal of microfinance which is income enhancement and vulnerability reduction requires to be supplemented by social capital building and other support strategies (Doyle, 1998).

PCEs are in extremely disadvantaged situation compared to other vulnerable societies where microfinance is used a strategy of socio-economic development, not only in terms of extremely poor physical infrastructure, economic and organizational structures of diminished capacity, but also with weakened social capital through loss of trust, diminished interaction and weakened networks and increased tensions between different communities and groups, and in declining human capital through death and displacement, loss of selfesteem, and trauma. Add to these is the fact that these adverse impacts mostly affect the poor stratum of society who always are the most affected by armed conflicts. Conflict erodes the financial, economic and social capital of the poor and weakens their organizations thereby adding to their vulnerability. This situation requires microfinance work in post conflict environments to invest heavily on preparatory work such as capacity building (Wilson, 2001; Wlliams, Uch, \& Soeng, 2001). Therefore it is generally recognized that post conflict societies are characterized by high operating costs for microfinance institutions (Shaw \& Matthew, n.d). In PCEs non-financial services such as training, business development and social intermediation therefore are a must if microfinance work to be successful through they do not generate commercial rates of return. It is in this context the practicality of the dominant minimalist approach which focuses on financial best practices in post conflict environment is questioned by analysts.

The role of microfinance in PCE is in reconstruction and recovery at community-level and household-level. At this level for its special situation strategies addressing special vulnerabilities and lack of resources require prominence than in normal contexts of poverty and vulnerability. According to analysts this involves reconsideration of goals of microfinance in actual implantation of strategies in PCE. On the one hand the protectional objectives of microfinance (addressing issues of vulnerability) such as consumption oriented financing, subsistence production and risk-spreading diversification of household income becomes important (Doyle, 1998; Sebstad \& Monique, 2000; Wilson, 2001). On the other hand, secondary order goals of social capital building and capacity functions of microfinance also need to be accorded prominence. As Doyle (1998) correctly says there is a case for sequencing post-conflict microfinance interventions to focus initially on protection and subsequently, with the rebuilding of household asset bases and revival of economic activity, to shift the focus towards sustained income promotion. The stepwise implantation microfinance starting with protectional strategies of re-building of livelihoods, assisting clients to reach a threshold of income security from which they can launch higher-risk, higher-return income-generating therefore may be the suitable strategy in post conflict environments activities (Sebstad \& Monique, 2000).

\section{Methodology}

The principal data collection tools for this study were Focus Group Discussions and Key Informant Interviews. Small-scale entrepreneurs from villages in the war-affected regions in the country, including border villages, were selected purposely in consultation with microfinance service providers who were active in Community Based Organizations. Altogether ten Focus Group Discussions were conducted; two in Batticaloa District, two in Trincomalee District, one each in Ampara, Mullaitive, Mannar, Kilinochchi and Jaffna Districts and one in a border village in Anuradhapura in the North Central Province. The Batticaloa and Trincomalee are the fully conflict affected and largest Districts in the two regions. Focused group discussions in Batticaloa ${ }^{4}$ and Trincomalee were mixture of Tamil, Sinhalese and Muslim while those in the Northern

${ }^{4}$ There were several Tamils of mixed Portuguese parentage (Batticaloa Burgers) in one Focus Group Discussions conducted in Batticaloa. 
Province were exclusively Tamil and the one in the border village (Anuradhapura) was exclusively Sinhalese. Accordingly, we have maintained the ethnic-wise war affected community representation in the sample. All Focus Group Discussions were conducted in informal settings, often a residence of an entrepreneur or an office of a community based organizations. This method was mainly covered the demand side data and information for the analysis of client's perception regarding impacts, strengths and weaknesses of microfinance practices in the regions. Not more than 10 individuals were present at any one of the Group Discussions. Some of those who took part in the discussions have had experience in doing small-scale business before starting their present activity but the majority was newcomers with no experience at all. While the main focus of the discussions was on their experience as small scale entrepreneurs who were receiving microfinance support there were some discussions about their wartime experience and its impact on their present activities and socioeconomic condition.

Key Informant Interviews were conducted with community based organization officials, Grama Niladari and representatives of government banks, private banks, non-governmental organizations and non-financial institutions covering all the Districts to assess the service provisions from institutional point of view, namely, the nature of the service offered and also institutions related problems and difficulties operating in a situation where social issues like weakened infrastructure and general services and also strict security conditions. This method was applied mainly to cover the supply-side information required for the analysis. 100 officials of 100 branches of 20 microfinance organizations and 40 other government and private sector officials were interviewed. This sample selection is also maintained the district wise representation and expansion of branches of each organization. Further, the data collected through Focus Group Discussions were triangulated using the information obtained from key informants and information available in secondary sources. The interviews with government officials, bank personnel and representatives of nonbanking financial institutions were also used to collect secondary data about loan disbursement and repayment rate. Though the researchers would have liked to interview the security establishment, the circumstances, namely, the inability to get required approval from Colombo prevented it. In additions, several microfinance supported establishments were visited in order to assess the operational conditions and which also gave the researchers opportunity to conduct some casual discussions with the workers.

\section{Results and Discussion}

Microfinance Actors and Activities in Sri Lanka: In Sri Lanka, the origin of microfinance services can be outlined back to the early 1900s. In 1911, the British government passed legislation to set up credit cooperatives in Sri Lanka. However, the government did not interfere with the activities of the co-operatives in the initial phase up to 1942. Traditional village leaders like landlords and village headmen dominated the cooperative societies. These societies did not show much growth during the initial phase. Following the food shortages originated from the Second World War, the government got involved in the co-operative movement in the second phase that began in 1942 by bringing in initiatives like co-operative Agriculture Production and Sales Societies (CAPS) and provided credit facilities to them. As practiced today microfinance activity in Sri Lanka is both a traditional community activity and a tool for economic development, with the clientele being mainly the poor. Service is provided by a broad range of different organizations for purposes of poverty alleviation, social and community development and as a multi-faceted intervention tool in areas affected by conflict. On the whole microfinance intermediaries in Sri Lanka can be categorized into four groups as professional national level microfinance institutions, local Non-Governmental Organizations (NGOs), International Non-Governmental Organizations (INGOs) and government programs. These institutions/ programs vary largely in terms of their sources of funding, clientele, coverage, legal, and organizational structure, key stakeholders, main activities and services provided to target individuals/ households.

In the post independence period, the government concentrated largely on agricultural credit, particularly for paddy cultivation. These credit facilities were granted mainly through two state banks, the Bank of Ceylon and the Peoples' Bank at subsidized interest rates under various rural credit schemes with funds provided by the Central Bank. In 1964 the government established the Co-operative Rural Banks (CRBs) which was a major contribution in the field of microfinance. However, microfinance, in its strict sense, was not present in Sri Lanka until 1986. During 1986-1991 the government initiated an arrangement of policy measures to 
expand credit facilities to the poor under its poverty alleviation strategy. The Ministry of Finance and the Central Bank initiated the Regional Rural Development Banks (RRDBs) in 1986 as part of these initiatives. As a major poverty alleviation strategy, the government also launched the Janasaviaya Program in 1989 under which the beneficiaries were assisted with credit facilities for viable self-employment projects with a view to promoting income generating activities on a sustainable basis. The government expanded this work by establishing the Janasaviya Trust Fund (JTF) in 1990. The Small Farmers and Landless Credit Project were launched by the Central Bank in 1991. All these programs had some form of microfinance component.

In 1996, the government replaced the Janasaviya Program with the Samurdhi Development and Credit Scheme to promote income generating self-employment opportunities among the poor so as to raise their income levels. In 1997, the government established the Samurdhi Authority and its microfinance scheme under which the beneficiaries were eligible to obtain loans of up to Rs. 10,000 for undertaking a new income generating activity or expanding an existing business. As part of this venture Samurdhi Bank Societies (SBS) were set up throughout the country to promote savings and to disburse credit. Microfinance initiatives have now expanded and the other major institutions and programs that provide microfinance facilities today include Commercial Banks, Regional Development Banks, Sarvodaya Economic Enterprise Development Services (SEEDS), Gami Pubuduwa Scheme, Thrift and Credit Co-operative Societies (TCCSs), Janasakthi Banking Societies (in Hambantota) and Women's Development Federation (in Hambantota). Apart from these major Micro Finance Initiatives (MFIs), there are Hundreds of domestic and international organizations involved in small credit delivery spread all over the country.

The current laws of Sri Lanka do not permit NGO's to take deposits even from its members as the Banking and Finance Act of 1998 restricts deposits to only banks and finance companies. This prohibition covers all aspects of savings whether it is from members or non members or whether it is as a guarantee for a loan or not. If NGO's take any deposits, then they must deposit them in turn in regulated financial institutions and are not permitted to lend even a part of them. This is a major problem faced by locally based microfinance operators who face severe supply issues. This situation is further confounded by the fact that the NGO sector which is the main supplier of funds for small time local MFIs is also constrained by shortages of funds. In terms of current involvement of the government in microfinance, the Central Bank Rural Credit Department remains the key government agency responsible for rural credit and for microfinance outside the Samurdhi Authority. In fact, the difference in emphasis between rural credit and microfinance showed that no government agency is responsible for or focused on policy aspects of microfinance exclusively. In 1992, the Presidential Commission on Banking and Finance recommended that the Central Bank of Sri Lanka confine itself to its traditional supervisory role and shed its development role. Despite this, it began a new microfinance project, Poverty Alleviation Microfinance Project (PAMP), with Japanese funding and also continued to implement the Small Farmers and Landless Credit Program, and own majority shares in the RDBs.

The Central Bank of Sri Lanka, which is the government agency responsible for the supervision of banking and non banking agencies, has no capacity to supervise the large spectrum of microfinance agencies and the work spread all over the country. The Cooperative Department, responsible for supervising key agencies such as the CRBs and TCCS is equally incapable of even auditing its agencies. Thus, microfinance in Sri Lanka is by and large an unsupervised, unregulated area. Despite the substantial growth of microfinance in Sri Lanka in the last 20 years there has been no attempt to regulate the institutions providing this service. The key reason why some regulations are required is the huge amount of savings that the poor entrust to these organizations. As the individual amounts are small from a national perspective the key agencies such as Central Bank of Sri Lanka of the Finance Ministry do not appear to give this issue sufficient attention. At the moment there are no or only a very few safeguards for savers in these schemes including all NGO programs, the Cooperative Programs and even some of the government programs. As a result, many NGO's and even TCCSs have folded their operations but as the numbers are small no one is aware of the fact. This could become a serious problem in future. Compare with other countries, Sri Lanka has developed a highly diversified microfinance system in the region. A study of the supply of microfinance which was commissioned by GTZ ProMis indicated that around 9,000 access points were available throughout the country(GTZ, 2008). The World Bank's study of Country-level Effectiveness and Accountability Review, conducted in 2006, demonstrated that 14,000 
access points. However, by international standards the country's microfinance services operate at a low level. The core problem is the poor quality of the microfinance services offered, indicated by insufficient reaching out, low repayment, low cost efficiency and financial products which not client driven. This situation seriously threatens the sustainability of the offered financial services and their outreach to poorer households, micro and small enterprises. High costs and limited access to finance are the two of the most crucial obstacles faced by beneficiaries, especially those in rural areas.

The main causes of the poor performance of microfinance institutions lie in the inadequate qualification of the microfinance institution staff and the fact that the government of Sri Lanka has not yet designed a national sector policy for a sustainable microfinance sector. Another problem lies in the lack of an organized regulatory and supervisory structure which encompasses all microfinance institutions. While commercial banks engaged in the microfinance business are regulated and supervised by the Central Bank, and the work of savings and credit of co-operative societies are supervised by the Department of Co-operative Development, and Samurdhi Banks by the Samurdhi Authority of Sri Lanka. There is neither supervision nor regulation of microfinance services provided by international NGOs although they mobilize saving deposits from the general public. The microfinance service providers in the public sector are weakened by politically motivated debt relief often ahead of elections which seriously endangers the repayment culture among its clientele. Another cause is the insufficient infrastructure for training, further education and advisory services to provide immediate and relevant practical advice. The negative impacts which results from all of the above are the insufficient supply of financial services to needy people in the society and micro and small enterprises.

Over the past three decades, microfinance institutions in Sri Lanka have adopted innovative modes of providing services to the poor entrepreneurs. Two main approaches on the role of microfinance intermediation in poverty reduction can be identified ${ }^{5}$. In terms of the first approach that is portrayed as the financial best practice focused Institutionist Approach where the microfinance institutions offer only financial services in the form of credit. These microfinance institutions are unwilling to provide non-financial services due to multiple reasons ranging from high administrative costs to high transaction costs. In that sense, the primary focus of these microfinance institutions is institutional profit disregarding the social and poverty alleviation dimension of microfinance. The alternative to this approach which places high importance on social objectives is also practiced and often referred to as the Welfarist Approach is also practiced by some microfinance providers, especially NGO sector in Sri Lanka. According to the latter, the provision of credit alone will not guarantee that the recipients of credit use scarce capital in productive manner so that the recovery of loans is not ensured. It is interesting to note that these services are increasingly being recognized as an important component of microfinance intermediation as they are associated with the viability and sustainability of the enterprise. Moreover, it is believed that the viability and sustainability of enterprises will in turn ensure financial viability and sustainability of the relevant microfinance institutions (Herath, 2015; Remenyi, 2002).

Nearly 80 percent of Sri Lankan households, including more than 70 percent of low-income households, have access to some form of saving services. The Sri Lankan financial market is essentially a microfinance market with over 80 percent of households having total borrowings below Rs. 100,000 (GTZ, 2008).Female's participation in microfinance programs in Sri Lanka is very high compared with male participants (GTZ, 2010). The following table (Table 1) demonstrates that microfinance institutions such as TCCSs, PAMP, SFLCP and SEEDS captured very high percentage of female clients. High repayment culture is one of the major

\footnotetext{
${ }^{5}$ In the broad category of the commercial/institutionist approach there are two broad strategies, one that focuses on providing credit only (minimalist) and the other with primary objective of credit but providing support services such as capacity building to make credit, especially recovery, more successful (credit plus). are the strategies variously known as minimalist approach and credit-plus approach. The second category of approaches includes zero interest strategies and charity based strategies focusing on social objectives of improving living conditions in its holistic sense, not just economic. As these do not have financial viability as main focus they need to depend on donor funds.
} 
reasons for increased women's participation in microfinance in Sri Lanka. In addition, some of international NGOs and programs purposely targeted women according to their program objectives and aims.

Table 1: Women's Participation in the Selected Credit Programs as at December 2007

\begin{tabular}{lccccl}
\hline Institution & $\begin{array}{l}\text { No. of loans } \\
\text { Male }\end{array}$ & Female & Total & $\begin{array}{l}\text { Value } \\
\text { Rs. Million }\end{array}$ & $\begin{array}{l}\text { \% received } \\
\text { by women }\end{array}$ \\
\hline RDBs & 50,804 & 43,277 & 94,081 & 1,614 & 46.00 \\
LCBs & N.A* & N.A* & N.A* & N.A* & N.A* \\
SDB & 321,687 & 246,896 & 568,583 & 13,000 & 43.42 \\
TCCSs & 36,726 & 85,696 & 122,422 & 2,816 & 70.00 \\
CRBs & 316,142 & 135,490 & 451,632 & 8,999 & 30.00 \\
PAMP & 12,604 & 39,388 & 51,992 & $1,058.4$ & 75.76 \\
SFLCP & 669 & 8,681 & 9,350 & 244.5 & 92.84 \\
SEEDS & 11,540 & 23,081 & 34,621 & 1,986 & 66.67 \\
\hline
\end{tabular}

N.A* - refers to the non-availability of disaggregated data

Source: Central Bank of Sri Lanka, Annual Repot (2008).

It also must be noted here that microfinance industry having reached a certain maturity level in Sri Lanka, has now gone beyond the area of micro credit and into financial services that cover micro savings, micro credit, and micro insurance.

Economy and Livelihoods in Conflict Affected Areas: Of the population of Northern and Eastern provinces around $80 \%$ is employed in agricultural crops, livestock and fisheries production. Out of those, 72 percent are homesteaders with less than 0.1 ha of back garden. Approximately 15-20 percent of the agricultural areas (comprising highly productive arable land) consists of high security zones and cannot be used for cultivation or for any other productive activities. There are also areas that still not cleared of landmines. Around thirty years of violent conflict coupled with the large scale and widespread destruction brought by the 2004 Tsunami also has taken its toll on the economy, primarily on agricultural production, of North and Eastern Provinces Sri Lanka. Together with the on-going assistance for resettlement, reconstruction and rehabilitation, there is a need to increase economic production for general improvement of living conditions of the people in the provinces. Strengthening of the small businesses sector by supporting locally manufactured agro-based products and improving of market opportunities is crucial for economic stability of the productive sectors. There is also an urgent need to increase agricultural productivity in order to improve food security among the affected population.

North and East are part of the dry zone of the country and economy is dominantly agriculture. In the Northern Province agriculture contributes around 28\% to region GDP yet 38\% of employed population was in agriculture (Sarvanathan, 2007). North and east are significant producers of food, cash crops, livestock and fish. The major agricultural crops are rice, union, green chili, potatoes and tobacco. The region accounts for $1 / 3$ of rice production of the country. As its population is only $15 \%$ country's population there is a surplus. North and East has been the largest livestock producer since independence. Animal husbandry consists of cattle rearing, goat/sheep farming and chicken. Buffalos are also kept but mainly in the east. According to recent data cattle and chicken are the most popular animal husbandry practice in the region with about 500,000 heads of cattle farmed mainly for milk and over 1.6 million chickens for meat and eggs. There are also about 170,000 heads of sheep of which around half is in Jaffna.

The second biggest livelihood of the region is fishing with sector contributing $12 \%$ to the GDP of the North East and has around 110,000 fishermen of which around 60\% is in the East. Fish production was severely affected during the conflict due to restrictions imposed by the government. With advent of peace the production has picked up and today the two provinces account for $35 \%$ of marine fish production of the county. The total marine fish production from the region in 2011 was 134,690 MT of which the Eastern Provinces share was 88,320 MT (65.5\%). Fishing in the region is done using mainly small mechanized fiber glass boats and mechanized and non mechanized traditional crafts. Over 50\% fishing vessels in Batticaloa are 
non mechanized traditional craft. Due to these technological constraints fishing is still carried out in near sea. Of economic activities industrial sector is the least developed. Since the construction of the cement factory in Kankasanthrurai in Jaffna there has not been any industries established in the Eastern Province by the government. The Industrial work force in the region is employed in micro small and medium enterprises the majority of which was either destroyed or damaged during the conflict. Statistics also show that during the conflict industry related employment halved from $8 \%$ to $4.4 \%$ with the biggest decrease in Jaffna, Batticaloa and Ampara (Sarvanathan, 2007).

Even before the conflict the economy of the North and East was going through changes resulting from the economic reforms brought in by the government that came into power in 1977. The impact of these policies however affected the North and the East differently. Unlike the economy of the country that saw fundamental changes in the composition of the economic production with the share of agriculture of the GDP which was $30 \%$ in 1970 coming down in 2005 to $18 \%$ and that of service increasing from $43 \%$ to $55 \%$ the same did not happen in the North and East. In the North and East, the share of agriculture remained around 35\% of the regional GDP with the weak service sector and industrial sector continuing. The impact of liberalization was felt in the Tamil speaking North and Eastern region in a different way. It severely affected the market in the South for the northern producer, especially Jaffna farmer. Liberalization of imports in late 1970s resulted in the decline of the South's dependence on of Jaffna agricultural produce. Conflict added to these problems by paralyzing the already affected northern economy. It destroyed much of the infrastructure of the region. North South links, transport of goods and people and also communication, were severely disrupted and came to near total stand still during the height of the war. Closure of A9 road and damage to the railway line stopping the service altogether and embargo of sending goods and restriction on fishing which is the main livelihood of people in the coastal areas, by the government and LTTE placing similar restrictions severely damaged the economy of the region. The thriving agriculture based economy that prospered and supplied the south with its many agricultural produce transformed from a successful commercial mode of production to survival mode of production as a result of the conflict (Sarvanathan, 2007).

Four years after the war short-term needs have been answered to a large extent through various programs. There are at present two major programs for reconstruction of the former war areas; one for the East is called Neganahira Navodaya (Eastern Awakening) and the other is called Uthuru Vasanthaya (Northern Spring). Both are government funded programs of development aimed at rebuilding the destroyed infrastructural facilities, mainly the road network and power and water supply. In addition, there are also livelihood development programs, notable among them are Gamaneguma and Gemidiriya working in tandem with government's major poverty alleviation program Samadhi. There are also other development attempts that target specific areas and activities like the Arugam Bay and Pasikudatourist promotion zones, Trincomalee special economic zone covering 675 sq.km of area and Kilinochchi 300 acre agro economic zone. The conflicts affected not only in the Northern and Eastern provinces and neither the Tamil community alone in the country. It also affected the so called border villages in the boundaries of these two provinces. These are dominated by the majority Sinhalese and agricultural (mainly paddy) settlements. A substantial number of villages are new settlements established since the independence. The Muslim community also affected by the conflict with 90,000 Muslims expelled from Jaffna by the LTTE and large areas of the Eastern Province which were home to the Muslims physically threatened by the LTTE and the population being displaced. Paddy cultivation in Ampara was the most affected. The Muslims expelled from Jaffna are still languishing in camps in the North Western coastal belt of the country, especially in Puttalam. Their removal created a vacuum in the economy of Jaffna town by removing a very enterprising population involved in trade. This no doubt affected the market links with the south which is a major market for agricultural produce of the Northern region.

War did not affect all regions of the North and the East equally. North was more affected as the center of militant activities. The District of Kilinochchi where the LTTE headquarters was and the District of Mullaitivu received the brunt of the last battle with extreme devastation of life and property. Over 250,000 civilians were displaced during the last stages of the war mainly from these two Districts. Unlike that Jaffna which is the capital of the Northern Province since 1995 was under government control and was relatively free of large scale conflict. Trincomalee the capital of the Eastern Province was also relatively unscathed. Compared 
to the North the effect of the conflict in the East was less. Except for parts of rural Batticaloa and Trincomalee outlying areas of the east was free of conflict since mid 1990 and was almost totally free since 2006. In addition to the economy and general services and public entitlements like Samurdhi and other poverty alleviation and welfare programs were not operative in almost totally in Mannar, Mullaitive and Killinochchi and partly in other areas. Population displacement was another problem. Alternatively, Diasporas are also found be having a positive effect on the home country though in the Sri Lankan context the role of the Tamil Diaspora is seen in a negative light for their role in supporting the militants. They bring money into the household and through that to the economy. Among the Sri Lankan Tamil Diaspora this role was important. During the conflict period they not only supported the militancy but also supported the households and the community through different type of active engagements like building services and facilities. Home Village Associations, Old Boys/Girls Organizations Tamil Diaspora found to playing an important role in the life of the people that have a cushioning effect on the life of the people in the area and also that can be harnessed is for success of future activities. Tamils in Canada have provided substantial funds for humanitarian assistance and play an important role in development effort (Cheran, 2007; Wimalaraja \& Cheran, 2010). While militancy role is no more and active community engagement has come down for the obvious reasons the support from the household remains at the same level.

Microfinance Actors, Strategies and its Impacts on Communities in Conflict Affected Areas: Yet the conflict kept away the main government sponsored microfinance initiatives reaching the potential beneficiaries during the conflict. Although continued access to finance was provided by local cooperatives, many branches had to be closed down and others to severely restrict their operations. Commercial banks provided saving facilities, but access to credit and credit-plus services remained difficult therefore the little microfinance initiatives during the conflict period were the ones sponsored by the NGO sector and funded through international donors and relief and development agencies. While the government sponsored programs are making their entry with the end of the war still microfinance services are primarily provided by the NGO sector. During the conflict, financial services in the region faced severe constraints owing to the acts of both the government and the militants. The result was once vibrant credit operations coming to a standstill and the region being deprived of the benefits of early attempts by the government to introduce microfinance in the country. Now that the conflict is over microfinance services are entering the regions. While the prewar credit culture is a potential plus factor for their work the conflict caused damage makes it necessary for the post conflict microfinance initiatives to adopt strategies to suit the conditions presented by the post conflict environment. The destruction of the physical infrastructure apart there are other adverse conditions such as the breakdown of the support services, especially financial service, shortage of personnel with skills caused by migration, greatly reduced opportunities for economic activities, weakened market (displacement and migration) and also disillusioned and traumatized population is severally hampering the efforts of newly entered microfinance operators. It is therefore not surprising to see a plethora of strategies that are being tried by different initiatives in this context.

The operators of microfinance programs in the North and East are mixed group that include banks, authorized non-banking sector operators like finance companies and leasing companies, International Donor Organizations and operators in the Non Governmental sector both local and international. This latter group includes local, regional and national level organizations who depend on external funding and large international NGOs who either operate on their own or through local agents. The strategies of microfinance initiatives in the north and east of the country can be seen as influenced by two factors, namely, the mission and the objectives of the service provider and the ground realties. Banks and other financial service providers have generally employ various shades of credit only strategies. Their approach could be called institutionist/minimalist in broad sense yet some of them provide some non-financial services as well (credit plus). The International NGOs, national NGOs, and UN and other bilateral donors on the other hand pay equal attention to financial best practices and social best practices both. There are also small local level NGOs with primary focus on relief and welfare while providing credit. The latter two groups of operators were providing similar services when there was ongoing conflict. International operators carry out their services either directly with their own schemes, like the GTZ or through local organizations that are funded by them. The biggest nongovernmental local operators are the Sarvodaya SEEDS, Seva Lanka and Sanasa/TCCCs (GTZ, 2010). In addition, the state sector also funds initiatives through local banks and also as part of general 
poverty alleviation programs the most active of these are the Samurdhi and Gemidiriya. A distinct characteristic of the conflict environment was that most microfinance clients were relatively well-off before the conflict but fell into poverty as a result of the conflict. Therefore, when they returned to their homeland, they only needed a kick-start to recommence productive economic activities, in sharp distinction with the slower commencement of persistent poor elsewhere.

Almost all microfinance initiatives in conflict areas use group loan approach to deliver their services. Members of a group loan facility can vary and are from a homogeneous group who come together to obtain credit to address their common economic problems. The groups that are commonly found in the region are, in addition to the five-member group, a format that was popularized by the countries pioneering poverty alleviation program Janasavia, SHGs, CBOs and other traditional village based volunteer organizations. The format depends on objectives of the livelihood program, funding source, target group, and service delivering methodology of the operator. They are encouraged to make voluntary savings on a regular basis but this is not mandatory and sometimes it is not even possible as some microfinance operators are not authorized to keep deposits. Operators provide credit from the savings if that is allowed under the law or from funds received from other agencies including banks. This process i.e. saving, lending, and recovering setting terms and conditions and keeping financial accounts helps in building financial discipline and more importantly, credit history for members themselves. Group members also learn to handle larger sums of money which are much beyond their individual savings. This process also makes them understand the basic principle of banking that money has a time value and is a scare resource. Poor women are particularly empowered by this type of microcredit strategy, as it gives them ability to earn an income and thus improve their bargaining positions vis-a-vis their male partners and in the community as well. This finding, which is in consisting withHerath (2015) and Noreen (2011), concluded that poor and vulnerable women having positive impacts by microfinance intervention for their livelihood development. However, Daley-Harris \& Zimmerman (2009) pointed out that microfinance dose not usually serve the very poor including poor women, for whom it can represent a rout into debt rather than a way out of poverty.

We found that microfinance activities have both encouraged and also created other intangible benefits too. There are many cases of cross ethnic cooperation in organized microfinance activities in multiethnic neighborhoods. This is a very common occurrence in Trincomalee and Batticaloa. This cooperation found to be having a multiplier and outward expanding effect. When the neighborhood group is multiethnic unit the market also becomes that of multiethnic clientele and suppliers as well. One very good example of this was a microfinance venture in Sirimapura ward of Trincomalee organized by a group of Sinhala and Muslim women. Their main economic activities are door to door selling of clothing items, catering and fish products. The clothing items are bought from Pamunuwa in Maharagama from mainly Sinhala traders by Muslim women and their clients are from all three ethnic communities. The producers and clientele of the other two activities similarly are multiethnic. Also Bernal-Garcia (2008) pointed out that the intervention of microfinance can have a socio-psychological effects through process mitigation of divergence among the different groups, besides its obvious economic impact. At the basis of this mechanism is the development of social contacts across individuals and groups.

Since the Post conflict environment is complex, conflict does not affect all in a conflict region equally. There are also regional differences in terms of impact with some areas experiencing more adverse impact than others. There is also differential impact of conflict on individuals and social groups. Our study showed that in some areas and with some groups the success rate is more and this is due to various factors ranging from their capacities, experiences and overall destruction in the region as a whole. The poor and the vulnerable groups are the most affected and their war experience, damage to property and levels of trauma if far greater than those belonging to well-to-do social groups. There are war widows, displaced people and ex-combatants who have very different war time experience from each other and also from those who generally from upper social strata. Therefore, it is not possible to make microfinance engagement in post conflict environment without taking these complexities and diversities into account. Thinking of a uniform strategy is not possible and may be unproductive. These two variables in combination make several potential target groups with different capacity levels. The Table 2 gives a broad classification of the potential targets groups, their features and potential for success through microfinance initiatives. 
Table 2: Different Target Groups, their Strengths and Weakness and Potential for MF Success

\begin{tabular}{|c|c|c|c|c|c|}
\hline \multirow[b]{2}{*}{ Target Group } & \multicolumn{4}{|c|}{ Characteristics } & \multirow[b]{2}{*}{$\begin{array}{l}\text { Potential for MF } \\
\text { Success }\end{array}$} \\
\hline & Trauma & Skills & Capacities & Opportunities & \\
\hline Refugees & Extreme & Vary & None & None & None \\
\hline Resettled & Recovering & Vary & Little & Little & Good \\
\hline $\begin{array}{l}\text { Rehabilitated } \\
\text { Ex-Combatants }\end{array}$ & Recovering & $\begin{array}{l}\text { Better but not } \\
\text { necessarily } \\
\text { useful }\end{array}$ & Less & Little or None & $\begin{array}{l}\text { Good to } \\
\text { very good }\end{array}$ \\
\hline War Widows & High & Little & $\begin{array}{l}\text { Little or } \\
\text { None }\end{array}$ & $\begin{array}{l}\text { Little or } \\
\text { None }\end{array}$ & $\begin{array}{l}\text { Least potential } \\
\text { for success }\end{array}$ \\
\hline $\begin{array}{l}\text { Other Female } \\
\text { Headed HHs }\end{array}$ & $\begin{array}{l}\text { Little or } \\
\text { Recovering }\end{array}$ & Little & Little & $\begin{array}{l}\text { Moderate to } \\
\text { High }\end{array}$ & $\begin{array}{l}\text { Better than war } \\
\text { widows }\end{array}$ \\
\hline $\begin{array}{l}\text { Not affected but } \\
\text { in the Conflict Area }\end{array}$ & $\begin{array}{l}\text { None or } \\
\text { very little }\end{array}$ & High & High & High & Very High \\
\hline
\end{tabular}

In the conflict affected Northeastern region, there are several distinct groups of potential beneficiaries with different needs, skills and capacities. The opportunities available to them are also different. The message there is that microfinance initiatives need to consider these circumstances and develop their intervention strategies accordingly. The package therefore needs to be a tailor made one to meet the differential needs of planned target group. Provision of credit alone will not guarantee that the recipients of credit use scarce capital in productive manner. Credit-plus services that include mainly the services that would assist entrepreneurs and the self-employed in developing their businesses are provided with, or prior to, the provision of key financial services. These services are increasingly being recognized as an important component of microfinance intermediation as they are associated with the viability and sustainability of the enterprise. These findings are consistent with Remenyi (2002), Colombage, Ahmad, \& Chandrabose (2008) and Herath et al. (2016) highlighted that there is a significant difference between households who received credit with credit-plus services and those that received credit without credit-plus services on income increases. Credit-plus services benefitted the households to improve their level of income by the investment projects. The viability and sustainability of enterprises will in turn ensure financial viability and sustainability of the relevant microfinance institutions. Moral issues apart, there is also the question that microcredit is the best support for some groups. The following model outlines possible interventions with particular attention to the above complexities (Table 3).

Table 3: Different Vulnerable Groups and Possible Interventions Strategies

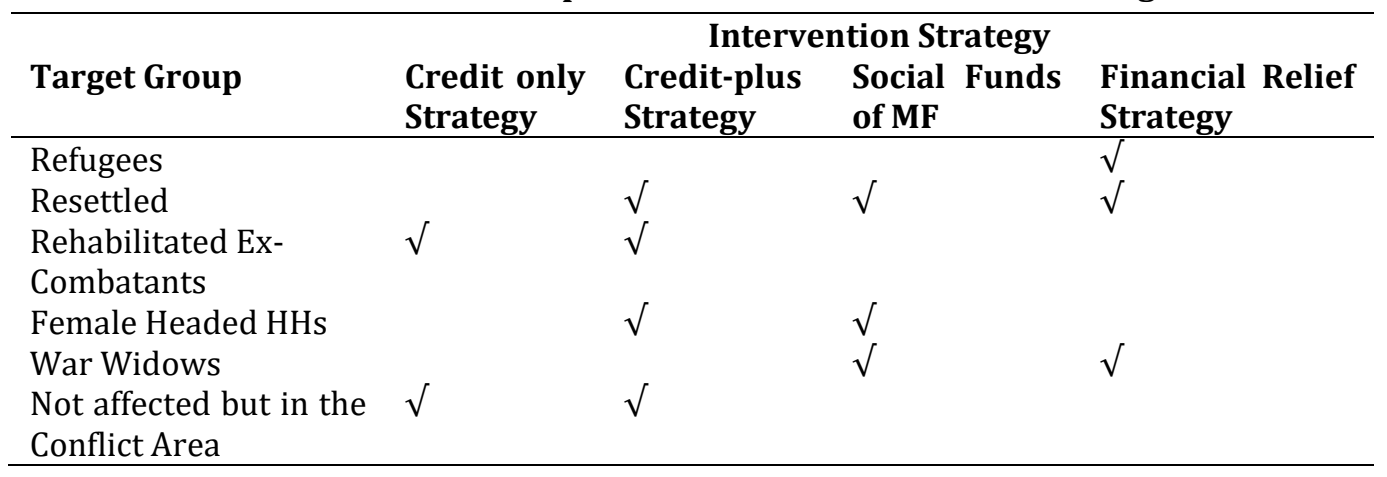

The needs to endorse groups and other social mechanisms for the useful delivery of microfinance services have long been recognized. Relevance of groups for microfinance interventions are in two main areas. First, they are means of achieving objectives, namely, to harness social capital/resources in effective and positive manner. Second, they are also basis of planning interventions. This second role of groups is important any 
intervention by microfinance initiative but it become particularly relevant in post conflict environment for its built in complexities.

\section{Conclusion and Recommendations}

Though the North and East of the country had a vibrant agriculture based economy and a developed credit culture supported by a range of institutions, large scale microfinance engagement is primarily a post war phenomenon. Although it is early to make a comprehensive assessment the available secondary information and our field observations show that microfinance initiatives in the region are making an impact on the livelihood improvement of clients. The impact however is in varying degrees with certain areas and groups showing evidence of receiving more beneficial impacts on some communities compared to others. It also showed very high involvement of women and those women who are active in generally the ones who can be called empowered, namely, those from groups above the very poor and those who have comparatively better educational levels. Another interesting feature of successful microfinance venture groups display high level of support role played by husbands and also high levels of community cohesion. Another feature of the ongoing microfinance initiatives is that the relative concentration of successful ventures in areas that were relatively free of conflict. These include main towns, except a few like Kilinochchi and Mullaitive and rural areas that had been liberated before the final phase of the war and remained under government control for a long period. There are two reasons for this. First, in urban areas there is better market and also access to financial services and other facilities are high. There are as not being subjected to fighting directly there is less damage to infrastructural facilities, or having remained under government control for a longer period there is such facilities have been rebuilt. Second, other adverse conditions such as market distortions, lack of people with skills and reduced social capital, etc., caused due to population shifts/displacement of people is less felt in these areas.

Microfinance strategies have both encouraged and also created other intangible benefits such as cross ethnic cooperation with organized microfinance activities in multiethnic neighborhoods. This is a very common occurrence in Eastern region. This cooperation is found to be having a multiplier and outward expanding effects. When the neighborhood group is multiethnic unit the market also becomes that of multiethnic clientele and suppliers too. In a post conflict environment, conflict has not affected all in a region equally. There are also regional differences in terms of impact with some areas experiencing more unfavorable impacts than others and the impact of conflict on individuals and social groups also could be different. This study showed that in some areas and with some groups benefitted from microfinance more. This is mainly due to various factors ranging from their capacities, experiences, knowledge and overall destruction in the region as a whole. The poor and the vulnerable are the most affected and their war experience, damage to property and levels of trauma if far greater than those belonging to well-to-do social groups. There are war widows, displaced people and ex-combatants who have very different war time experience from each other and also from those who are generally from upper social strata. Therefore, it is not possible to make microfinance intervention in post conflict environment without taking these complexities and divergence into account.

Northeastern region in Sri Lanka is not a monolithic entity. There are several distinct groups of potential clients with different requirements, abilities and capacities. The economic and income earning opportunities available to them are also different. Therefore, the microfinance intermediaries need to be taking into consideration these conditions in high priority and design their intervention strategies accordingly. The microfinance package needs to be a tailor made one to achieve the multiple requirements of intended target groups. Provision of credit alone will not guarantee that the recipients of credit use scarce capital in a productive manner. Credit-plus services would assist entrepreneurs and the self-employed in developing their businesses are provided with, or prior to of key financial services. Apart from moral issues, there is also the question whether microcredit is the best support for some groups. It is necessary to endorse groups and other social mechanisms for the useful delivery of microfinance services which have long been recognized. Relevance of groups for microfinance interventions are in two major areas. First, they are means of achieving objectives, namely, to harness resources in effective and positive manner. Second, they are also basis of 
planning interventions. This second role of groups is important any intervention by microfinance initiative but it become particularly relevant in post conflict environment with its built in complexities.

\section{References}

Bernal-Garcia. (2008). Post-Conflict Microfinance and Social Reconciliation: Overcoming Barriers through Process Mitigation. Standford Journal of Microfinance, 1(3).

Chambers, R. (1995). Poverty and Livelihoods: Whose Reality Counts? Brighton: Institute of Development Studies.

Cheran, R. (2007). Transnationalism, Development and Social Capital: Tamil Community Networs in Canada. In G. Luin \& K. Sailajah (Eds.), Organizing the Transnational: Experience of Asia and Latin American Migrants in Canada (pp. 277-305). Vancouver: The UBS Press.

Christen, R. \& Drake, D. (2002). Commercialization of Mocrofinance. In D. Drake \& E. Rhyne (Eds.), Commercialization of Microfinance: Balancing Bussiness and Development. Bloomfield, CT: Kumarian Press.

Claessens, S. (2006). Access to Financial Services: A Review of the Issues and Public Policy Objectives: The World Bank.

Colombage, S. S., Ahmad, A. \& Chandrabose, A. S. (2008). Effectiveness of Microfinance in Reducing Rural Poverty: A Case Study of Selected Districts Sri Lanka. VISTAS, Journal of Humanities and Social Seinces, 4, 1-37.

Daley-Harris, S. \& Zimmerman, J. (2009). Microfinance Does not Usually Serve the Very Poor, for Whom it Can Represent a Rout into Debt rather than Away Out of Poverty Enterprise Development and Microfinance, 20(2), 79-85.

Doyle, D. (1998). Microfinance in the Wake of Conflict: Challenges and Opportunities. Microenterprise Best Practices (MBP) Paper. Retrieved from www.mbp.org website:

GTZ. (2008). Outreach of financial Services in Sri Lanka, A Look at Demad-Side from a Microfinance Perspective, Sri Lanka Colombo: German Development Cooperation, Ministry of Finance and Planning.

GTZ. (2010). Promotion of the Microfinance Sector Operational District Profile. Colombo: GTZ.

Herath, H. M. W. A. (2015). Impact of Microfinance on Poverty Reduction: Evidence from Sri Lanka. Modern Sri Lanka Studies A Journal of the Social Sciences, 6(1), 79-102.

Herath, H. M. W. A., Guneratne, L. H. P. \& Sanderatne, N. (2016). Impact of microfinance on women's empowerment: a case study on two microfinance institutions in Sri Lanka. Sri Lanka Journal of Social Sciences, 38(1), 51-61.

Littlefield, E., Morduch, J. \& Hashemi, S. (2003). Is Microfinance an Effective Strategy to Reach the Millennium Development Goals? Focus Note 24. Washongton DC: CGAP, Wold Bank.

Lock-Desallien, R. (1996). Review of Poverty Concepts and Indicators Technical Support Document: UNDP.

Marconi, R. \& Mosely, P. (2006). Bolivia during the Global Crisis(1008-2004): Towards a Macroeconomics of Microfinance. Journal of International Development, 18, 237-261.

Meehan, D. \& Jennifer, M. (1999). Working Towards Institutional Financial Self-Sufficiency while Maintaining a Commitment to Seving the Poorest families. Joural of Microfinance, 1(1), 131-192.

Morduch, J. (2000). The Microfinance Schism. World Developmwnt, 4(28), 617-629.

Muneer, S., Ali, A. \& Ahmad, R. A. (2017). Impact of Financing on Small and Medium Enterprises (SMEs) Profitability with Moderating Role of Islamic Finance. Information Management and Business Review, $9(2), 25-32$

Noreen, S. (2011). Role of Microfinance in Empowement of Femal Population of Bahawalpur District. Paper presented at the International Conference on Economics and Finance Research, IPEDR. http://www.microfinancegateway.org/p/site/m//template.rc/1.9.53772

Otero, M. \& Rhyne, E. (1994). The New World of Microenterprise Finance. West Hartford, CT: Kumarian Press.

Rappaport, J. (1986). Collaborating for Empowerment: Creating the language of mutual Help In R. H. Boyte (Ed.), The New Populiss: The Politics of Empowerment. Philadelphia: Temple University Press.

Remenyi, J. (2002). Microfinance: A Tool for Poverty Reduction. Sri Lanka Journal of Agrarian Studies, 10(1), $52-69$. 
RIMHI. (1999). Guatemala: Never Again! The Official Report of the Human Rights Office, Archiocese of Guatemala. Maryknoll, New York.

Sarvanathan, M. (2007). Economy of the Conflict Region in Sri Lanka: from Embargo to Repression. Washington: East West Centre.

Sebstad, J. \& Monique, C. (2000). Microfinance, Risk Management and Poverty. Washington DC: USAID.

Shaw, J. \& Matthew, C. (n.d). Risky Business in Bougainville: Implementing Microfinancein Post-Conflict Environments. RMIT University: International Develoment Programme, Melbourne.

Whitmore, E. K. P. (1988). Participation, Empowerment and Welfare. Canadian Review of Social Policy, 22, 5160.

Wilson, T. (2001). Microfinance during and after Armed Conflict: Lessons from Angola, Cambodia, Mozambique and Rwanda. Durham, UK: Springfield Centre.

Wimalaraja, I. \& Cheran, R. (2010). Empowering Diasporas: The Dynamics of Post War Transnational Tamil Politics Burghof Occational Paper. Berlin: Bughof Peace Support.

Wliams, A., Uch, V. \& Soeng, V. N. (2001). Post-Conflict Microfinance in Cambodia. Durham, UK: Springfield Centre.

Woller, G. M., Christopher, D. \& Warner, W. (2001). Where to Microfinance? Microcredit and Development Policy, 1(1).

World-Bank. (2002). Wold Development Report. New York: World Bank. 